\title{
HYDROCHEMICAL VARIATIONS OF THE SPRINGS OF JINFO MOUNTAIN, CHONGQING, CHINA
}

\author{
HIDROKEMIJSKE SPREMEMBE IZVIROV NA GORI JINFO, \\ CHONGQING, KITAJSKA
}

\author{
Xiao QIONG ${ }^{1,2 *}$, Shen LICHENG $^{2} \&$ Wu KUNYU ${ }^{3}$
}

\begin{abstract}
UDC 556.36:556.114(510)

Xiao Qiong, Shen Licheng \& Wu Kunyu: Hydrochemical variations of the springs on Jinfo Mountain, Chongqing, China

There are 18 springs within the Jinfo Mountain area of Chongqing, SW China (of which 10 epikarst springs are within the National Nature Reserve, and 4 epikarst springs and 4 non-epikarst springs are outside the National Nature Reserve). The hydrochemical characteristics of these springs were measured in 1977, 2004-2009, and 2011. The data show that the hydrochemistry type of springs in different areas, and for different years, is $\mathrm{Ca}-\mathrm{HCO}_{3}$ and $\mathrm{Ca}-\mathrm{HCO}_{3}-\mathrm{SO}_{4}$, whereas the concentrations of $\mathrm{SO}_{4}^{2-}$ and $\mathrm{NO}_{3}^{-}$are very sensitive to changes in human activities. All the springs with the highest $\mathrm{SO}_{4}^{2-}$ and $\mathrm{NO}_{3}^{-}$concentrations in the study area showed minimum concentrations in 1977 and an upward trend in concentrations from 2004 to 2008, followed by a period of lower concentrations. Springs with low $\mathrm{SO}_{4}^{2-}$ and $\mathrm{NO}_{3}^{-}$concentrations were distributed solely at the top of Jinfo Mountain in the National Nature Reserve. The hydrochemical variations observed in springs on Jinfo Mountain demonstrate that the implementation of environmental policy measures and industrial restructuring have successfully contributed to environmental protection of the springs.
\end{abstract}

Key words: Hydrochemical variations, $\mathrm{SO}_{4}^{2-}, \mathrm{NO}_{3}^{-}$, human activities, Jinfo Mountain.

Izvleček

UDK 556.36:556.114(510)

Xiao Qiong, Shen Licheng \& Wu Kunyu: Hidrokemijske spremembe izvirov na gori Jinfo, Chongqing, Kitajska

$\mathrm{Na}$ območju gore Jinfo v Chongqingu, JZ Kitajska je 18 izvirov (10 epikraških izvirov je znotraj nacionalnega naravnega rezervata, 4 epikraški in 4 ne-epikraški izviri pa so izven tega območja). Hidrokemijske značilnosti teh izvirov so bile merjene v letih 1977, 2004-2009 in 2011. Po zbranih podatkih sta $\mathrm{v}$ različnih območjih in za različna leta hidrokemijska tipa izvirov $\mathrm{Ca}-\mathrm{HCO}_{3}$ in $\mathrm{Ca}-\mathrm{HCO}_{3}-\mathrm{SO}_{4}$, koncentracije $\mathrm{SO}_{4}^{2-}$ in $\mathrm{NO}_{3}^{-} \mathrm{pa}$ so zelo občutljive na spremembe $\mathrm{v}$ človekovih dejavnostih. Vsi izviri z najvišjimi koncentracijami $\mathrm{SO}_{4}^{2-}$ in $\mathrm{NO}_{3}^{-} \mathrm{v}$ študijskem območju so imeli najnižje koncentracije v letu 1977, sledil je trend naraščanja koncentracij v letih od 2004 do 2008, nato pa so bile koncentracije spet nižje. Izviri z nizkimi koncentracijami $\mathrm{SO}_{4}^{2-}$ in $\mathrm{NO}_{3}^{-}$so razporejeni le na vrhu gore Jinfo v nacionalnem naravnem rezervatu. Opazovane hidrokemijske spremembe izvirov na gori Jinfo kažejo, da je izvajanje ukrepov okoljske politike in prestrukturiranje industrije uspešno prispevalo k zaščiti izvirov.

Ključne besede: hidrokemijske spremembe, $\mathrm{SO}_{4}^{2-}, \mathrm{NO}_{3}^{-}$, človekove dejavnosti, gora Jinfo.

\footnotetext{
${ }^{1}$ Key Laboratory of Karst Dynamics, MLR \& Guangxi, Institute of Karst Geology, Chinese Academy of Geological Sciences, Guilin 541004, China.

${ }^{2}$ School of Geographic Sciences, Southwest University, 1 Tiansheng Rd., Chongqing 400715, China.

${ }^{3}$ School of Resources and Environment Engineering, Southwest Petroleum University, Chengdu 610500, China.

${ }^{*}$ Corresponding author: Xiao Qiong, Key Laboratory of Karst Dynamics, MLR \& Guangxi, Institute of Karst Geology, Chinese Academy of Geological Sciences, Guilin 541004, China, e-mail: xiaoqiong-8423@163.com
}

Received/Prejeto: 11.04 .2014 


\section{INTRODUCTION}

Water is a key resource for human populations, required for drinking and irrigation (Hoek et al. 2001; Kirda 1997), but water scarcity and pollution have become an increasingly important problem in recent years, especially in karst areas. A large typical karst area is found in SW China, covering an area of about $620,000 \mathrm{~km}^{2}$, and with a population of 100 million (Zhang et al. 2006; Peng et al. 2011).This karst area is a rich water resource that includes groundwater and epikarst springs. The epikarst zone is important to the storage and migration of the karst water resources, and is very sensitive to human activities because of the "soil upstairs and water downstairs" phenomenon in the karst area.

The hydrochemical features of epikarst springs are probably determined by (1) the interaction of water with soil and rock, (2) allogenic water mixed with epikarst water, and (3) human activities that affect the epikarst water (Zhu \& Qian 2005). Many studies have proposed that studying the hydrochemistry of hydrological systems not only reflects the natural conditions, such as soil, vegetation, and lithology, but also provides important information on anthropogenic additions from agricultural activities, industrial sewage discharge and etc. (Stallard \& Edmond 1981, 1983, 1987; Edmond et al. 1996; Gaillardet et al. 1999a, b; Grosbois et al. 2000; Barth et al. 2003; Lee et al. 2007; Raymond et al. 2008; Guo et al. 2010). Epikarst springs develop in the epikarst zone, an irregular karst zone occurring in surface carbonate rocks that consists of various individual and micro karst forms resulting from strong karstification processes. Precipitation and surface waters may readily drain into the complex network of subterranean karstic conduits, being retained within the aquifer for long periods before eventually re- emerging elsewhere as a spring. With rapid economic growth and population increase, land use has become one of the most important influences on the quality and viability of groundwater springs, especially in karst areas. Agricultural irrigation, industrial waste, and domestic waste have largely contributed to the contamination of springs. Concentrations of nitrate and sulphate have shown notable increases as a result of the application of large amounts of chemical fertilizers used in agriculture (Compton \& Boone 2000; Jiang et al. 2008). Waste water and waste residues produced by the construction of factories and homes cause an increase of pollutants such as nitrogen and sulphate (Wakida \& Lerner 2006). Several previous studies have examined the links between human activity and the hydrochemistry of springs in China (Jia \& Yuan 2003; Zhang \& Yuan 2004).

Jinfo Mountain (Mt. Jinfo) in Chongqing, SW China, is a typical subalpine karst area, and a key research area for karst water systems (Zhang et al. 2011; Gao et al. 2008), land utilization (Li et al. 2005; Zhang 2010), and biodiversity (Dai 2002; Liao et al. 2008). In this study, 14 epikarst springs and 4 non-epikarst springs at different altitudes on Mt. Jinfo were selected specifically for monitoring and a comparison of their hydrochemical variations for 1977, 2004-2009, and 2011. The aim of this study is to investigate the hydrochemical behaviours of springs in subtropical mountainous regions similar to Mt. Jinfo and to gain a general understanding of longterm geochemical variations of epikarst springs and their response to the application of environmental policies and industrial restructuring over these years.

\section{STUDY AREA}

Mt. Jinfo is located in the south of Chongqing, China, southeast of the Sichuan Basin (Fig. 1). It is part of Dalou Mountain Range, a typical karst landform formed with 108 peaks. Mt. Jinfo is approximately situated in the area $28^{\circ} 50^{\prime} \mathrm{N}-29^{\circ} 20^{\prime} \mathrm{N}, 107^{\circ} 00^{\prime} \mathrm{E}-107^{\circ} 15^{\prime} \mathrm{E}$, and the highest elevation (above sea level) is $2251 \mathrm{~m}$ (Wang \& Wang 1990). Mt. Jinfo was named as "the National Forest Garden of China" in 1991.

The vertical changes in climate and vegetation from the foot to the top of Mt. Jinfo are significant, including a temperature difference of c. $5-6^{\circ} \mathrm{C}$. The top of the mountain exhibits similar characteristics to temperate climates, with an annual average air temperature of $8.5^{\circ} \mathrm{C}$, annual mean rainfall of $1396 \mathrm{~mm}$, and a rainy season from April to October. However, the lower part of the mountain has a subtropical humid monsoon climate, typical for SW China, with an annual average air temperature of $16.6^{\circ} \mathrm{C}$, annual rainfall of $1287 \mathrm{~mm}$, and a rainy season from February to August (Zhang et al. 2011).

The geological structure of this area is a wide and gentle syncline, and includes fault structures along the NE-SW-oriented major tectonic line. The carbonate rock outcrop covers approximately two-thirds of the entire study area. The surface of Mt. Jinfo is underlain by 




Fig. 1: Map of sampling sites at

Mt. Jinfo.

Sample locations:

1 - Hongyanzui spring;

2 - Shunlongqiao spring;

3 - Penglailin spring;

4 - Jinfoshan spring;

5 - Zhiyinshanzhuang spring;

6 - Sanwenyu spring;

7 - Bitang springs;

8 - Dongfanghong spring;

9 - Caizigou spring;

10 - Xiaoni spring;

11 - Shuifang spring;

12 - Dengjiapuzi spring;

13 - Dawandao spring;

14 - Shuanglongdong spring;

15 - Changgangling spring;

16 - Toudu spring;

17 - Changba spring (a),

18 - Changba spring (b).

Permian limestone $\left(\mathrm{P}_{1}\right)$ above $2000 \mathrm{~m}$ a.s.l., and largescale karst formations are found in both the surface and subsurface. From 1000 to $1500 \mathrm{~m}$ a.s.l., the mountain is covered with Silurian shale and sandstone. Below $1000 \mathrm{~m}$ a.s.l. the mountain is composed of Cambrian limestone and Ordovician dolomite (Fig. 1, Tab. 1). The aquifer system in this region is controlled by the large-scale karst formations, and predominantly formed by karstic fissures and caves. Since the epikarst zone here is largely covered by vegetation, epikarst springs are ubiquitous on Mt. Jinfo. As a National Forest Garden, the land use pattern in the National Nature Reserve (NNR) on Mt. Jinfo 
Tab. 1: The geological and hydrochemical features of the springs ( $\mathrm{pH}$ and electrical conductivity are presented as the average values from 2004 to 2009; and discharge and temperature as the range of measured values in 1977, 2004-2009, and 2011).

\begin{tabular}{|c|c|c|c|c|c|c|c|c|}
\hline Spring & Location & $\begin{array}{c}\text { Elevation } \\
m\end{array}$ & $\begin{array}{l}\text { Exposed } \\
\text { strata }\end{array}$ & Lithology & $\begin{array}{c}\text { Discharge } \\
\left(m^{3} / d\right)\end{array}$ & $p H$ & $\begin{array}{c}\text { Electrical } \\
\text { conductivity } \\
\mu S / \mathrm{cm}\end{array}$ & $\begin{array}{c}\text { Temperature } \\
{ }^{\circ} \mathrm{C}\end{array}$ \\
\hline 1 & $28^{\circ} 39^{\prime} 09^{\prime \prime} \mathrm{N} ; 107^{\circ} 08^{\prime} 48^{\prime \prime} \mathrm{E}$ & 630 & Permian & limestone & $0.01-0.1$ & 7.40 & 441 & $18.7-19.3$ \\
\hline 2 & $29^{\circ} 09^{\prime} 10^{\prime \prime} \mathrm{N} ; 107^{\circ} 10^{\prime} 59^{\prime \prime} \mathrm{E}$ & 640 & Permian & limestone & $0.2-0.3$ & 7.42 & 439 & $15.9-17.2$ \\
\hline 3 & $29^{\circ} 08^{\prime} 02^{\prime \prime} \mathrm{N} ; 107^{\circ} 12^{\prime} 13^{\prime \prime} \mathrm{E}$ & 649 & Ordovician & limestone & $0.01-0.1$ & 7.20 & 484 & $17.8-18.2$ \\
\hline 4 & $29^{\circ} 07^{\prime} 38^{\prime \prime} \mathrm{N} ; 107^{\circ} 12^{\prime} 17^{\prime \prime} \mathrm{E}$ & 684 & Cambrian & dolomite & $0.1-0.15$ & 7.52 & 480 & $16.2-16.5$ \\
\hline 6 & $29^{\circ} 03^{\prime} 24^{\prime \prime} \mathrm{N} ; 107^{\circ} 12^{\prime} 31^{\prime \prime} \mathrm{E}$ & 655 & Ordovician & limestone & $2-2.2$ & 7.90 & 180 & $18.9-19.6$ \\
\hline 7 & $29^{\circ} 02^{\prime} 28^{\prime \prime} \mathrm{N} ; 107^{\circ} 08^{\prime} 16^{\prime \prime} \mathrm{E}$ & 766 & Cambrian & dolomite & $5-6$ & 7.92 & 318 & $14.2-14.8$ \\
\hline 8 & $29^{\circ} 03^{\prime} 09^{\prime \prime} \mathrm{N} ; 107^{\circ} 07^{\prime} 01^{\prime \prime} \mathrm{E}$ & 702 & Ordovician & limestone & $2.5-3.5$ & 7.86 & 266 & $14.5-14.8$ \\
\hline 9 & $28^{\circ} 59^{\prime} 56^{\prime \prime} \mathrm{N} ; 107^{\circ} 05^{\prime} 31^{\prime \prime} \mathrm{E}$ & 1289 & Ordovician & limestone & 0.01 & 7.81 & 456 & $14.1-15.6$ \\
\hline 10 & $29^{\circ} 00^{\prime} 51^{\prime \prime} \mathrm{N} ; 107^{\circ} 11^{\prime} 11^{\prime \prime} \mathrm{E}$ & 2072 & Permian & limestone & $0.55-0.7$ & 7.17 & 98 & $9.1-9.2$ \\
\hline 11 & $29^{\circ} 01^{\prime} 43^{\prime \prime} \mathrm{N} ; 107^{\circ} 10^{\prime} 54^{\prime \prime} \mathrm{E}$ & 2018 & Permian & limestone & $10-15$ & 7.67 & 278 & $8.6-9.8$ \\
\hline 13 & $28^{\circ} 58^{\prime} 33^{\prime \prime} \mathrm{N} ; 107^{\circ} 08^{\prime} 15^{\prime \prime} \mathrm{E}$ & 1373 & Ordovician & limestone & $0.2-0.25$ & 6.76 & 239 & $13.6-14.1$ \\
\hline 14 & $28^{\circ} 58^{\prime} 53^{\prime \prime} \mathrm{N} ; 107^{\circ} 11^{\prime} 51^{\prime \prime} \mathrm{E}$ & 1526 & Permian & limestone & $2-3$ & 7.89 & 367 & $9.2-9.7$ \\
\hline 15 & $28^{\circ} 57^{\prime} 02^{\prime \prime} \mathrm{N} ; 107^{\circ} 07^{\prime} 34^{\prime \prime} \mathrm{E}$ & 1344 & Silurian & detrital stone & $0.35-1.5$ & 7.37 & 393 & $12.9-13.0$ \\
\hline 16 & $28^{\circ} 56^{\prime} 14^{\prime \prime} \mathrm{N} ; 107^{\circ} 11^{\prime} 43^{\prime \prime} \mathrm{E}$ & 838 & Silurian & detrital stone & $1-3$ & 7.34 & 580 & $12.8-14.6$ \\
\hline 17 & $28^{\circ} 55^{\prime} 28^{\prime \prime} \mathrm{N} ; 107^{\circ} 09^{\prime} 08^{\prime \prime} \mathrm{E}$ & 791 & Silurian & detrital stone & $0.75-1$ & 7.31 & 423 & $18.7-19.9$ \\
\hline 18 & $28^{\circ} 55^{\prime} 28^{\prime \prime} \mathrm{N} ; 107^{\circ} 09^{\prime} 08^{\prime \prime} \mathrm{E}$ & 791 & Silurian & detrital stone & $0.75-1$ & 8.06 & 324 & $17.6-18.1$ \\
\hline
\end{tabular}

consists only of forestland, while cultivated land, a small amount of industrial and mineral land, and grassland makes up the area outside this reserve.

In order to examine and compare the relationships between hydrochemical variations under different vertical climatic conditions and human activities for 1977, 2004-2009, and 2011, epikarst springs at different elevations were selected: springs $4-12$ and 14 are within the NNR (Fig. 1), whereas springs $1-3$ and 13 are located outside the NNR. Additionally, four non-epikarst springs (15-18) were included in the study. All 18 of the springs represent the most important sources of domestic water for local people. Springs 9-15 are at elevations of more than $1000 \mathrm{~m}$ (above sea level), with springs 10 and 11 representing the highest springs at the top of Mt. Jinfo (elevations of $2072 \mathrm{~m}$ and $2018 \mathrm{~m}$ respectively). Springs $1-6,8$, and $16-18$ are at elevations of 630-838 m. Springs $1,2,10$, and 11 are exposed in the Permian strata with surrounding limestone lithology. Springs 3, 6, 8, 9, 12, and 13 are exposed in Ordovician strata, again with surrounding limestone lithology. However, springs 4, 5, and 7 are exposed in Cambrian strata surrounded by dolomite lithology, and the non-epikarst springs (15-18) are exposed in Silurian strata with surrounding lithology of detrital stone. All springs have perennial streams and show different discharges: less than $1 \mathrm{~L} / \mathrm{s}$ for springs $1-5$, $9,10,13,17$, and 18 ; between 1 and $10 \mathrm{~L} / \mathrm{s}$ for springs $6-8$ and 14-16; and 10-15 L/s for springs 11 and 12 (Tab. 1).

\section{STUDY METHODS}

\section{HYDROCHEMISTRY ANALYSIS}

The hydrochemical data of all springs for 1977 were gathered from the Nanjiang Hydrogeological \& Engineering Geology Brigade, and continued monitoring of these springs was carried out by authors from 2004 to 2011. The measurement method in 1977 consisted of basic chemical analysis in the laboratory. These historical analyses may lack precision; however, large changes in data values were observed between 1977 and 2004, and so the level of precision is within acceptable limits. Tem- perature (T), pH, electrical conductivity (EC), and $\mathrm{HCO}_{3}^{-}$ and $\mathrm{Ca}^{2+}$ concentrations for these springs were tested in the field. T, pH, and EC were measured using Portable Water Quality Analyzers (produced by Hach Company, USA). The analysers' accuracies are $0.1^{\circ} \mathrm{C}$ for $\mathrm{T}, 0.01$ for $\mathrm{pH}$, and $1 \mu \mathrm{S} / \mathrm{cm}$ for EC. $\mathrm{HCO}_{3}^{-}$and $\mathrm{Ca}^{2+}$ contents were measured by on-site alkalinity and calcium tests (Aquamerck, Germany), with an accuracy of $0.1 \mathrm{mmol} / \mathrm{L}$ and $2 \mathrm{mg} / \mathrm{L}$ for $\mathrm{HCO}_{3}^{-}$and $\mathrm{Ca}^{2+}$, respectively. $\mathrm{AgNO}_{3}$ titration $(0.1 \mathrm{mg} / \mathrm{L})$ was applied to measure the $\mathrm{Cl}^{-}$content, and 
an ultraviolet spectrometer $(0.01 \mathrm{mg} / \mathrm{L})$ to measure the $\mathrm{NO}_{3}^{-}$and $\mathrm{SO}_{4}^{2-}$ in the water sample. ICP-OES (Optima $2100 \mathrm{DV})(0.001 \mathrm{mg} / \mathrm{L})$ was used to measure the cation content after the water samples were acidified and antiadsorbed. All laboratory experiments were completed in the Water Chemistry Analysis Laboratory in the School of Geographical Sciences, Southwest University, China.

\section{KRIGING INTERPOLATION METHOD}

The most common methods for spatial interpolation are Inverse Distance Weighting (IDW) and the Kriging method. Previous research has determined that the Kriging method is more accurate in its retention of original image features (Milillo \& Gardella 2008), and in estimating radioactive contamination (Mabit \& Bernard 2007) and soil mercury content (Hu et al. 2004). On the other hand, the IDW method is superior for estimating whole landfill methane flux (Spokas et al. 2003). Kriging interpolation has been widely used in spatial data analysis. The general equation of this method can be expressed (Matheron 1963; Li et al. 2000) as:

$Z\left(x_{0}\right)=\sum_{i=1}^{n} \lambda_{i} Z\left(x_{i}\right)$

where $\mathrm{i}=1,2,3 \ldots n, \mathrm{Z}\left(x_{0}\right)$ is the estimated variable value for the estimated point, $\mathrm{n}$ is the number of measured points in a given range (here the springs on Mt. Jinfo), and $\mathrm{Z}\left(x_{\mathrm{i}}\right)$ is the value of the measured points. In this study the concentrations of $\mathrm{SO}_{4}^{2-}$ and $\mathrm{NO}_{3}^{-}, \lambda_{\mathrm{i}}$ are the kriging weightings.

Suitable weightings of $\lambda_{i}$ are determined by two conditions. One is that $\mathrm{Z}\left(x_{0}\right)$ and $\mathrm{Z}\left(x_{\mathrm{i}}\right)$ must have the same average value throughout the whole field, written as:

$\sum_{i=1}^{n} \lambda_{i}=1$

The other condition is that the kriging variance should take the smallest possible value, as estimated by:

$\sigma^{2}=\sum_{i=1}^{n} \lambda_{i} \gamma\left(x_{i}, x_{0}\right)+\mu-\gamma\left(x_{i}, x_{0}\right)$

where $\mu$ is the Lagrange multiplier and $\gamma\left(x_{\mathrm{i}}, x_{0}\right)$ is the semivariogram, which can be estimated by the equation below:

$\gamma(h)=\frac{1}{2 n} \sum_{i=1}^{n}\left[Z\left(x_{i}\right)-Z\left(x_{i}+h\right)\right]^{2}$

where the vector $\mathrm{h}$ is the distance between $x_{\mathrm{i}}$ and $x_{0}$.

\section{RESULTS AND DISCUSSION}

\section{GENERAL WATER CHEMISTRY DESCRIPTION}

Epikarst springs on Mt. Jinfo generally displayed neutral $\mathrm{pH}$ (average $\mathrm{pH}$ from 2004 to 2009 was between 6.76 and 8.34 ), and temperatures ranging from $8.6^{\circ} \mathrm{C}$ to $23.6^{\circ} \mathrm{C}$. The EC (average EC from 2004 to 2009) of the springs in the NNR was c. $168-564 \mu \mathrm{S} / \mathrm{cm}$, and c. $239-584 \mu \mathrm{S} / \mathrm{cm}$ outside the NNR. The non-epikarst springs in the study area were similar to the epikarst springs in terms of $\mathrm{pH}$, EC, and temperature (Tab. 1).

For all springs, $\mathrm{HCO}_{3}^{-}$was the dominant anion for the majority of samples (c. $31.97-380.93 \mathrm{mg} / \mathrm{L}$ ), followed by $\mathrm{SO}_{4}^{2-}$ (concentration $1.88-147.84 \mathrm{mg} / \mathrm{L}$ ). $\mathrm{Ca}^{2+}$ was the dominant cation for the majority of samples (c. $8.52-139.06 \mathrm{mg} / \mathrm{L}$ ), followed by $\mathrm{Mg}^{2+}$ (concentration 1.88-46.94 mg/L). $\mathrm{SO}_{4}^{2-}$ and $\mathrm{NO}_{3}^{-}$ (c. $0-75.36 \mathrm{mg} / \mathrm{L}$ ) showed relatively large interannual variability, whereas those of $\mathrm{Cl}^{-}$(c. $0-14.82 \mathrm{mg} / \mathrm{L}$ ), $\mathrm{Na}^{+}$(c. $\left.0-26.62 \mathrm{mg} / \mathrm{L}\right)$, and $\mathrm{K}^{+}$(c. $\left.0-6.08 \mathrm{mg} / \mathrm{L}\right)$ did not vary significantly. Major ion compositions are shown in the anion and cation ternary diagrams (Fig. 2). $\mathrm{SO}_{4}^{2-}$ and $\mathrm{HCO}_{3}^{-}$together accounted for $80 \%$ to $95 \%$ of the total anions in the majority of samples. In general, $\mathrm{Ca}^{2+}$ and $\mathrm{Mg}^{2+}$ dominated the cation concentrations of the spring waters, accounting for more than $80 \%$ of the total cation concentrations in the majority of epikarst springs (Fig. 2). Therefore, the hydrochemical watertype for these epikarst springs was $\mathrm{Ca}-\mathrm{HCO}_{3}$. The results also show that the four non-epikarst springs in this study had similar hydrochemical characteristics to the epikarst springs, which may indicate a common source of carbonate weathering for the major ions in all 18 springs.

Fig. 3 shows the cation triangular diagram for all springs for 1977, 2004-2009, and 2011. Major cation changes between years were not obvious for 1977 and 2004-2009. The triangular diagram for anions for 1977, 2004-2009, and 2011 (Fig. 4), shows that $\mathrm{HCO}_{3}^{-}$is the dominant anion for the majority of samples and, as for cations, no obvious changes are seen between these 


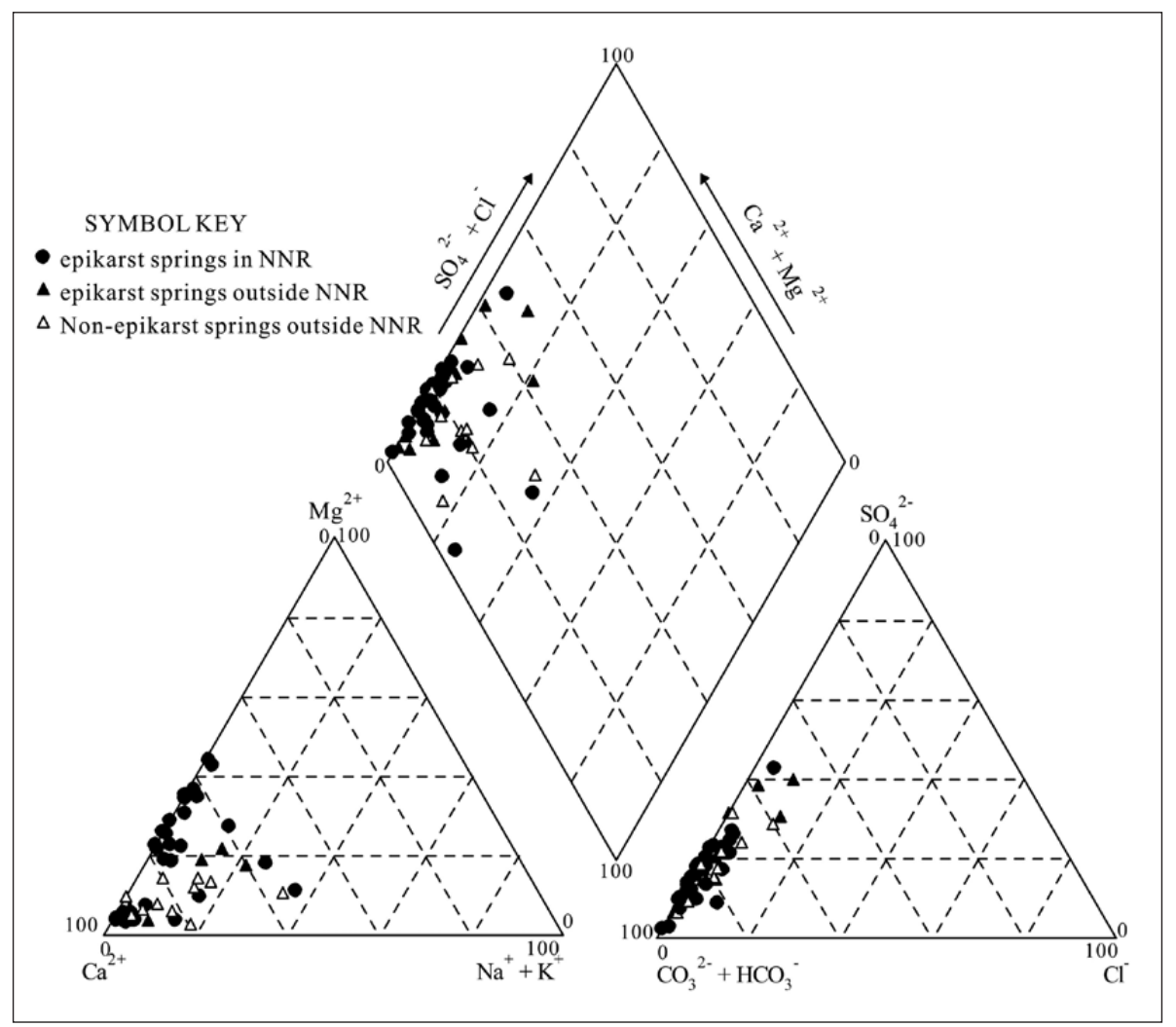

Fig. 2: Piper diagram of spring hydrochemistry at Mt. Jinfo.

years. Also, significant changes are not seen between springs in or outside the NNR, or between epikarst and non-epikarst springs.

\section{LITHOLOGY WEATHERING CONTROL ON WATER CHEMISTRY}

Different geological formation periods and lithology is the major factor controlling the groundwater chemistry.

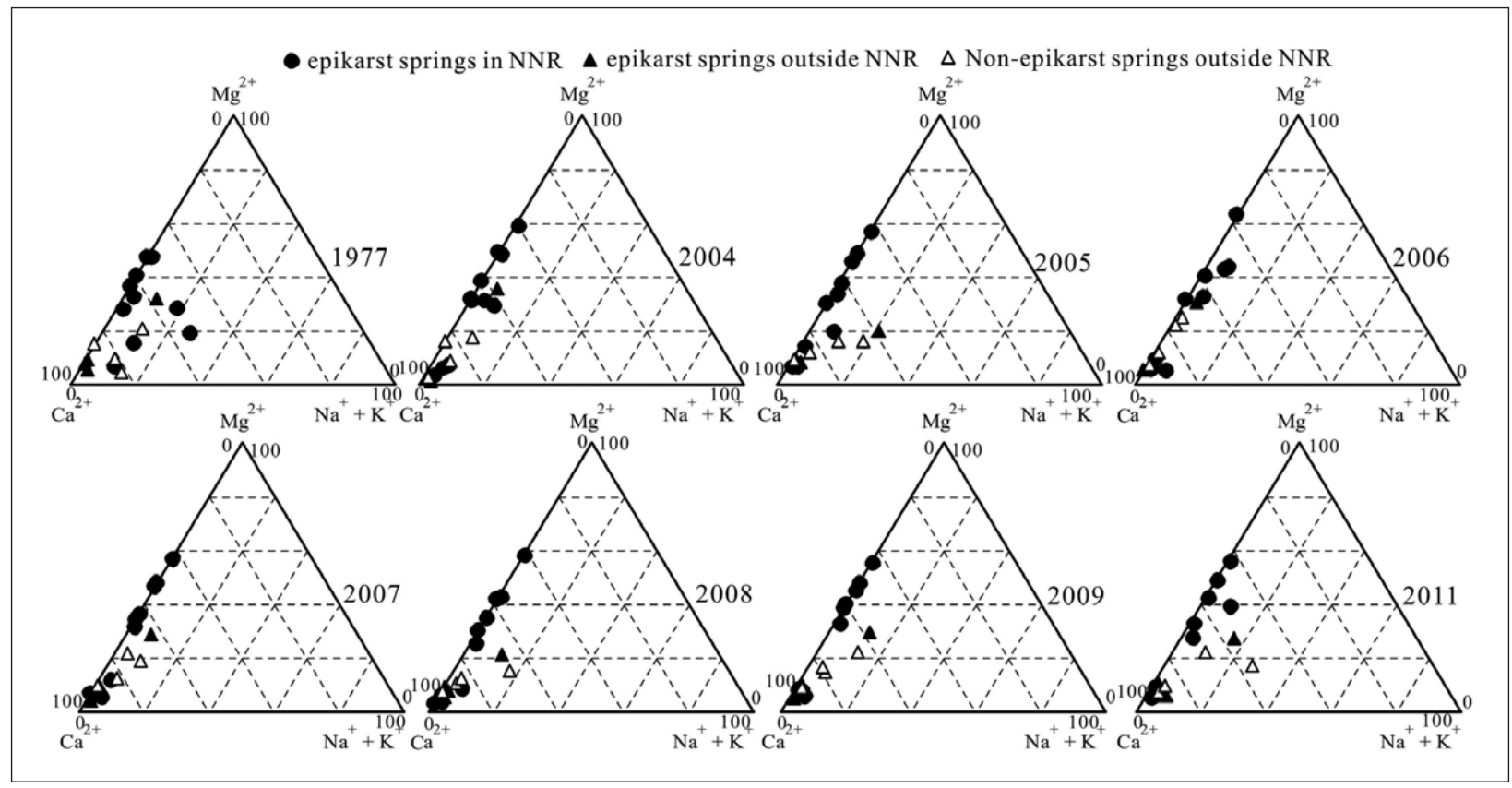

Fig. 3: Cation diagrams for the springs for 1977, 2004-2009, and 2011. 


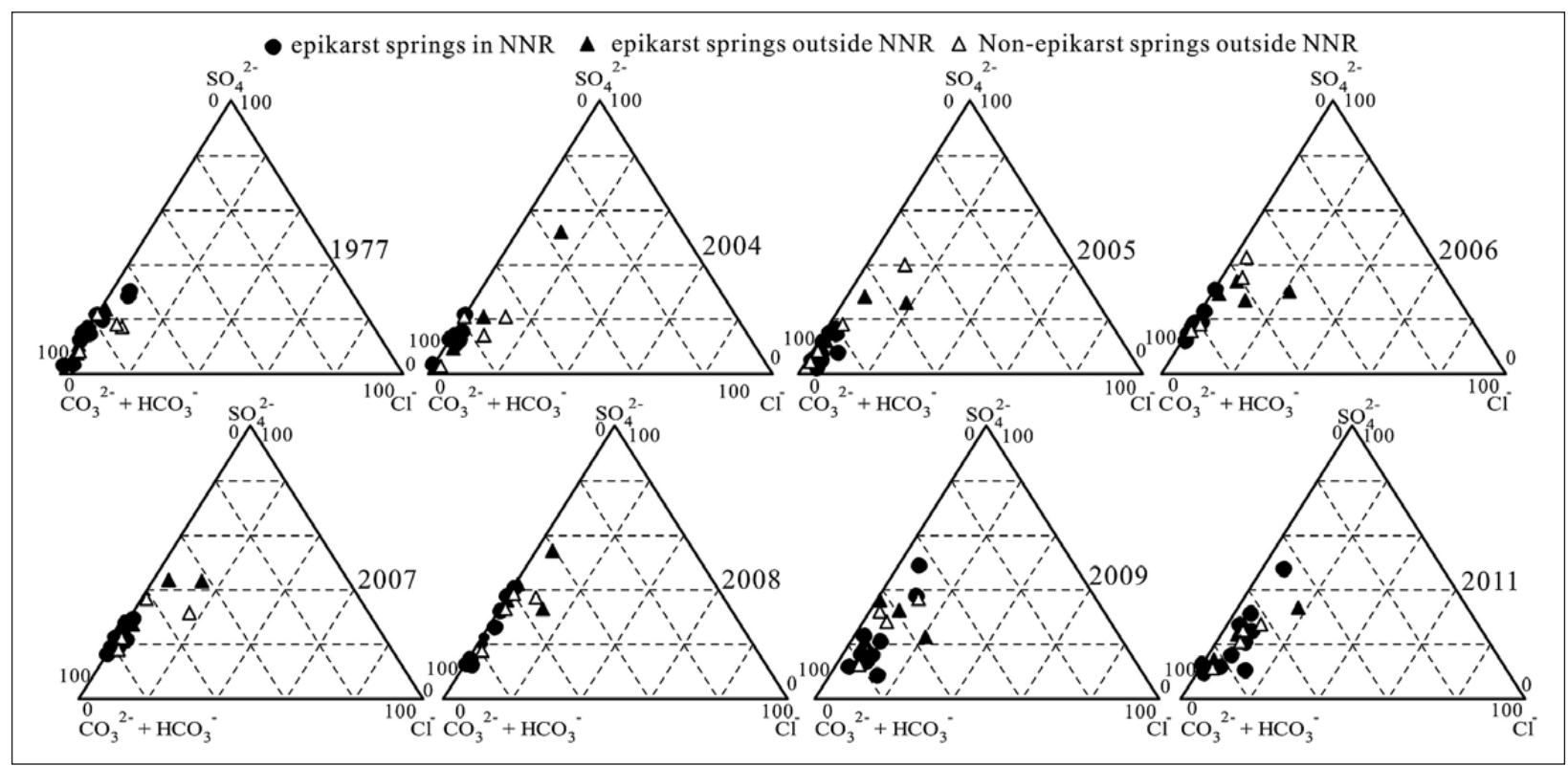

Fig. 4: Anion diagrams for the springs for 1977, 2004-2009, and 2011.

$\mathrm{HCO}_{3}^{-}$concentrations were plotted against $\mathrm{Ca}^{2+}$ concentrations for all Mt. Jinfo samples in different years (Fig. 5(a)). As expected, high linear correlation was obtained throughout the observation period (correlation coefficient $r=0.651$ ), which strongly suggests that the main lithology of Mt. Jinfo is limestone. The projection point of the contrast ratio of $\mathrm{Ca}^{2+}$ and $\mathrm{HCO}_{3}^{-}(\mathrm{mmol} / \mathrm{L})$ was near a best-fit curve, constrained to pass through $(0,0)$, gave a $\mathrm{Ca}^{2+} / \mathrm{HCO}_{3}^{-}$ratio of 0.5 (Fig. 5(b)), which implies that the weathering in this area was mainly carbonate weathering. It may be that significant quantities of limestone from Permian and Ordovician strata mixed with the detrital stone, with the result that weathering in detrital stone areas in Silurian also takes the form of carbonate weathering. This could explain the similar hydrochemical features between springs 15-18 and the other epikarst springs.

Fig. 6 shows that there is little variation in $\mathrm{Ca}^{2+}$ and $\mathrm{HCO}_{3}^{-}$concentrations of all springs for 1977, 2004-2009, and 2011. This is possibly because these two ion concentrations are controlled by carbonate dissolution, which is the main water/rock interaction in the karst aquifer. In Fig. 6, we can also observe that the concentrations of $\mathrm{Ca}^{2+}$ in the NNR were lower than for springs outside the NNR, which may be due to the negative influence on carbonate dissolution of the high altitudes and lower

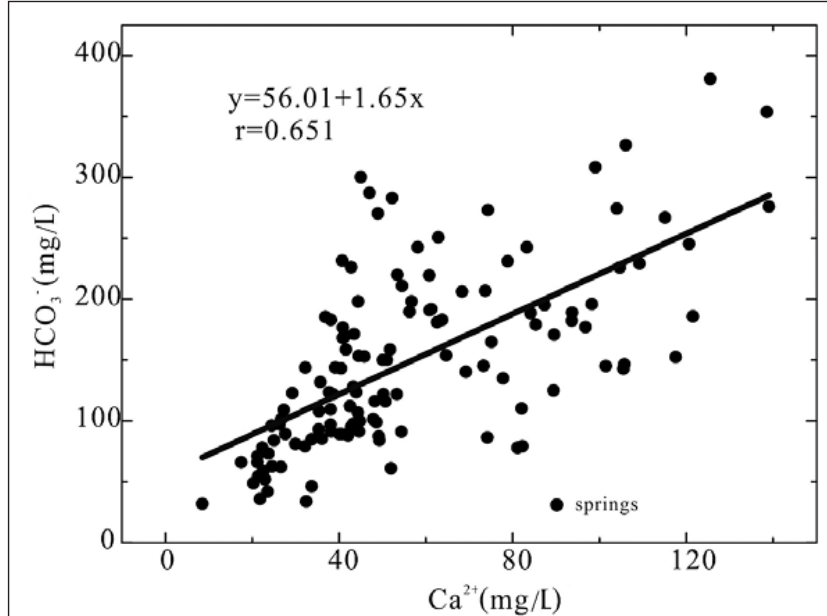

(a)

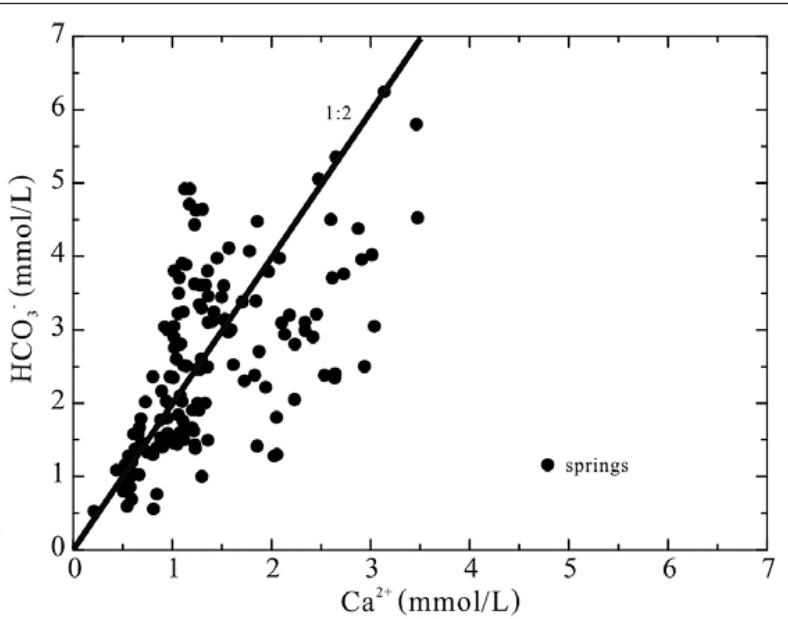

(b)

Fig. 5: (a) Relationship of $\mathrm{Ca}^{2+}$ with $\mathrm{HCO}_{3}^{-}$concentrations $(\mathrm{mg} / \mathrm{L})$; (b) Liner relationship between $\mathrm{Ca}^{2+}$ and $\mathrm{HCO}_{3}^{-}$concentrations $(\mathrm{mmol} / \mathrm{L})$. 


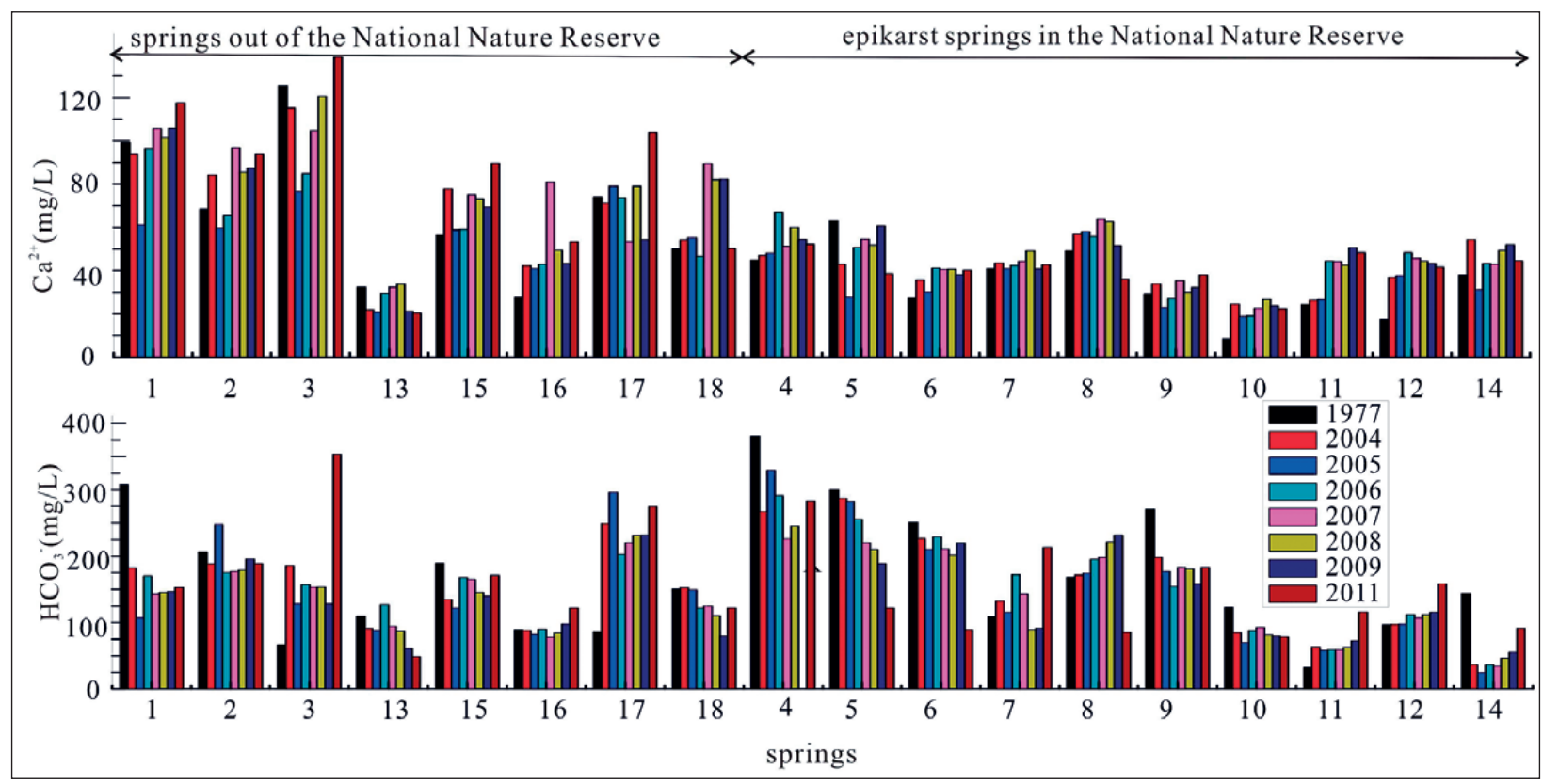

Fig. 6: Variation of $\mathrm{Ca}^{2+}$ and $\mathrm{HCO}_{3}^{-}$concentrations for springs for 1977, 2004-2009, and 2011.

temperatures of the springs in the NNR (Tab. 1). Furthermore, the concentration of $\mathrm{HCO}_{3}^{-}$for springs outside the NNR did not show obvious variations, and may therefore be influenced by other ions.

\section{EFFECT OF HUMAN ACTIVITIES ON EPIKARST SPRINGS}

A spatial interpolation method set out in the "Study methods" section was applied to process $\mathrm{SO}_{4}^{2-}$ and $\mathrm{NO}_{3}^{-}$concentration data for the 18 springs for 1977, 2004-2009, and 2011, to indicate the concentration variation of $\mathrm{SO}_{4}^{2-}$ and $\mathrm{NO}_{3}^{-}$in groundwater for the study area. The spatial interpolation method was used to indicate different grades by colour on a thematic map, and to illustrate the distribution of $\mathrm{SO}_{4}^{2-}$ and $\mathrm{NO}_{3}^{-}$concentrations for 1977, 2004-2009, and 2011 on Mt. Jinfo (Fig. 7). Concentration of $\mathrm{SO}_{4}^{2-}$ was lower than $40 \mathrm{mg} / \mathrm{L}$ in 1977 (Fig. 7(a)), and this value was used to reflect the natural low background levels of groundwater. According to the quality standard for ground water (GB/T 14848-93), $\mathrm{SO}_{4}^{2-}$ concentration $<50 \mathrm{mg} / \mathrm{L}$ in underground water is defined as water quality Class I. Obviously, all of the springs achieve water quality Class I in 1977 and the lowest $\mathrm{SO}_{4}^{2-}$ concentration was found at the top of Mt. Jinfo; this is due to the dilution of the groundwater by the abundant precipitation. $\mathrm{SO}_{4}^{2-}$ concentrations showed an upward trend from 2004 to 2008, then declined in 2009 and 2011. Most areas experienced increased $\mathrm{SO}_{4}^{2-}$ concentrations, and only the area surrounding the peak of Mt. Jinfo maintained the low concentration observed in 1977. The highest con- centration of $\mathrm{SO}_{4}^{2-}(>150 \mathrm{mg} / \mathrm{L})$ presented in the northwest and southeast of the study area, near Nanchuan city and Toudu town. Fig. 7(b) shows the interpolation map of the $\mathrm{NO}_{3}^{-}$concentrations in this study area and, as observed for sulphate, the lowest concentrations were seen in $1977(<15 \mathrm{mg} / \mathrm{L})$. In 2004, high $\mathrm{NO}_{3}^{-}$concentrations $(>50 \mathrm{mg} / \mathrm{L})$ were observed in the northwest of the study area, near Nanchuan city. This showed an upward trend from 2004 to 2007, then decreased in 2008 and 2009 $(<30 \mathrm{mg} / \mathrm{L})$ and returned to higher concentration in 2011 $\left(>50 \mathrm{mg} / \mathrm{L}\right.$ ). The areas showing high $\mathrm{NO}_{3}^{-}$concentrations in the study area changed over time, whereas districts with low $\mathrm{NO}_{3}^{-}$concentrations in the springs were distributed in Mt. Jinfo NNR.

The highest concentration of $\mathrm{NO}_{3}^{-}$is distributed near Nanchuan city and Toudu town, as is the highest $\mathrm{SO}_{4}^{2-}$ concentration. These areas of high concentration are located in the valley of Mt. Jinfo, where the terrain is relatively flat and major local settlements and farmland are located. Since the 1980s, rapid population growth and the large quantities of chemicals and fertilizers used in the industrial and agricultural sectors have resulted in large amounts of industrial waste, sewage, and fertilizer entering the groundwater system. Land use near Nanchuan city and Toudu town is predominantly cropland and construction land, but also includes many coal factories in the northeastern area and a large wine factory in Toudu town, which contribute to substantial increases in $\mathrm{SO}_{4}^{2-}$ and $\mathrm{NO}_{3}^{-}$concentrations in the area surrounding Mt. Jinfo. The concentrations of $\mathrm{SO}_{4}^{2-}$ and $\mathrm{NO}_{3}^{-}$reduced 


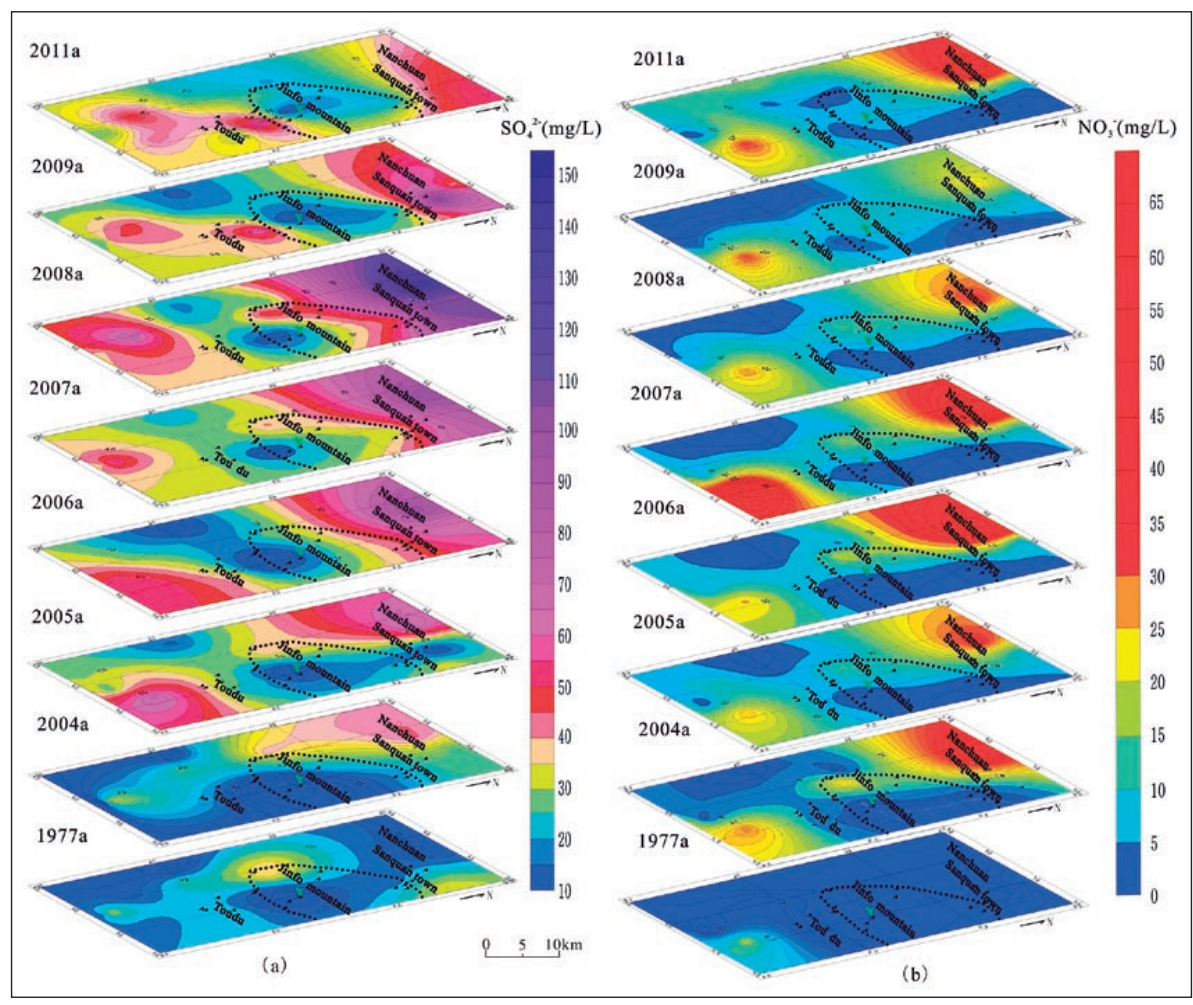

Fig. 7: Spatial and temporal variability of (a) sulphate and (b) nitrate contamination.

after 2008, especially in the districts of local settlements and farmland. We propose that this reduction is linked to local environmental policy measures and the implementation of industrial restructuring in 2006. The National agricultural sector focused on high-quality grain, and conducted soil testing and fertilizer work in some counties in 2005, with government support (Long 2008). In 2006, Nanchuan district also began to implement soil testing and fertilizer work and, remarkably, achieved reductions in $\mathrm{SO}_{4}^{2-}$ and $\mathrm{NO}_{3}^{-}$concentrations after 2008 . In recent years, the local government has prioritized the development, eco-tourism and forestry, and has modernized and restructured the industrial and agricultural sectors, thereby further reducing the generation of pollutants. In particular, a large of area of farmland was returned to forest, and eco-tourism and forestry were developed to replace the traditional agriculture and industry. The application of environmental policy and the implementation of industrial restructuring have had an obvious effect, showing that these policies were successful in aiding environmental protection.

\section{CONCLUSIONS}

The hydrochemical features of 18 springs on Mt. Jinfo were measured for 1977, 2004-2009, and 2011. Results indicated that there were no obvious changes in the major ion concentrations, and the hydrochemical type of these springs remains $\mathrm{Ca}-\mathrm{HCO}_{3}$. Because of the different land utilization for different areas near Mt. Jinfo, the concentrations of $\mathrm{SO}_{4}^{2-}$ and $\mathrm{NO}_{3}^{-}$in different springs was changed uncommonly in the past 35 years. Low concen- trations remained unchanged at the top of Mt. Jinfo in the NNR, where the only land use is forest. In contrast, agricultural fertilization, industrial pollution, and sewage discharge have affected the concentrations of $\mathrm{SO}_{4}^{2-}$ and $\mathrm{NO}_{3}^{-}$for the epikarst springs outside the $\mathrm{NNR}$ area, leading to an upward trend from 2004 to 2008 , followed by a decrease in 2009 due to the implementation of environmental policies and industrial restructuring. 


\section{ACKNOWLEDGEMENT}

This project was supported by the Guangxi Science Foundation (No. 2013GXNSFBA019221), the National Nature Foundation of China (No. 41302213), and the China Geological Survey project (Nos. 1212011087119;
12120113006700). Special thanks are given to Wangpeng, Caomin, and Gao Yanfang for their help with the fieldwork.

\section{REFERENCES}

Barth, J.A.C., Cronin, A.A., Dunlop, J. \& R.M. Kalin, 2003: Influence of carbonates on the riverine carbon cycle in an anthropogenically dominated catchment basin: evidence from major elements and stable carbon isotopes in the Lagan River (N. Ireland).Chemical Geology, 200, 203-216.

Compton, J.E. \& R.D. Boone, 2000: Long-term impacts of agriculture on soil carbon and nitrogen in New England.- Forests Ecology, 81, 8, 2314-2330.

Dai, Y.L., 2002: Study of the significances of biodiversity conservation in Jinfo Mountain karst area.- Territory and Natural Resources Study, 4, 48-50.

Edmond, J.M., Palmer, M.R., Measures, C.I., Brown, E.T. \& Y. Huh, 1996: Fluvial geochemistry of the eastern slope of the northeastern Andes and its foredeep in the drainage of the Orinoco in Colombia and Venezuela.- Geochimica et Cosmochimica Acta, 60, 2949-2976.

Gaillardet, J., Dupré, B., Louvat, P. \& C.J. Allègre, 1999a: Global silicate weathering and $\mathrm{CO} 2$ consumption rates deduced from the chemistry of the large rivers.- Chemical Geology, 159, 3-30.

Gaillardet, J., Dupré, B. \& C.J. Allègre, 1999b: Geochemistry of large river suspended sediments: silicate weathering or recycling tracer.- Geochimica et Cosmochimica Acta, 63, 4037-4051.

Gao, Y.F., Li, H.C., Shen, L.C. \& P.H. Yang, 2008: Geochemical characteristics and spatial distribution of spring water at Jinfo Mountain, Chongqing.- Geology in China, 35, 2, 322-331.

Grosbois, C., Négrel, P., Fouillac, C. \& D. Grimaud, 2000: Dissolved load of the Loire River: chemical and isotopic characterization.- Chemical Geology, 170, 179-201.

Guo, H., Simpson, I.J., Ding, A.J., Wang, T., Saunders, S.M., Wang, T.J., Cheng, H.R., Barletta, B., Meinardi, S., Blake, D.R. \& F.S. Rowland, 2010: Carbonyl sulfide, dimethyl sulfide and carbon disulfide in the Pearl River Delta of southern China: Impact of anthropogenic and biogenic sources.- Atmospheric Environment, 44, 3805-3813.
Hoek, W.V.D., Konradsen, F., Ensink, J.H.J., Mudasser, M. \& P.K. Jensen, 2001: Irrigation water as a source of drinking water: is safe use possible.- Tropical Medicine and International Health, 6, 1, 46-54.

Hu, K.L., Li, B.G., Lu, Y.Z. \& F.R. Zhang, 2004: Comparison of various spatial interpolation methods for non-stationary regional soil mercury content.- Environmental Science, 25, 132-137.

Jia, Y.L. \& D.X. Yuan, 2003: The impact of land use change on karst water in Shuicheng basin of Guizhou province.- Acta Geographica Sinica, 58, 6, 831-838.

Jiang, Y.J., Yuan, D.X., Zhang, C., Zhang, G. \& R. He, 2008: Impact of land use change on groundwater quality in a typical karst watershed of southwest China.- Hydrogeology Journal, 16, 4, 727-735.

Kirda, C., 1997: Assessment of irrigation water quality.Options Méditerranéennes, 31, 367-377.

Lee, K.S., Ryu, J.S., Ahn, K.H., Chang, H.W. \& D. Lee, 2007: Factors controlling carbon isotope ratios of dissolved inorganic carbon in two major tributaries of the Han River, Korea.- Hydrological Processes, 21, 500-509.

Li, L.L., Kuang, M.S., Zhang, Y.Z., Jiang, Y.Y., Shen, L.C. \& Y.Q. Li, 2005: $\mathrm{CO}_{2}$ concentration of the soil vegetation-system under different vegetation covers in karst area of Jinfo Mountain in Chongqing.- Rural Eco-Environment, 21, 3, 67-70.

Li, X., Cheng D. \& L. Lu, 2000: Comparison of spatial interpolation methods.- Advance in Earth Sciences, $15,3,260-265$.

Liao, Y.J., Yu, F.F., Liu, Z.Y. \& D.M. Xie, 2008: The biodiversity, conservation and sustainable utilization of macrofungi resources in the Jinfo Mountain Nature Reserve in Chongqing.- Ecological Science, 27, 1, $42-45$.

Long, W.J., 2008: Analysis on China's chemical fertilizer market in 2007 and prospects for the trend in 2008.Phosphate \& Compound Fertilizer, 23, 2, 1-5. 
Mabit, L. \& C. Bernard, 2007: Assessment of spatial distribution of fall out radio-nuclides through geostatistics concept.- Journal of Environmental Radioactivity, 97, 206-219.

Matheron, G., 1963: Principles of Geostatistics.- Economic Geology, 58, 1246-1266.

Milillo, T.M. \& J.A. Gardella Jr., 2008: Spatial analysis of time of flight-secondary ion mass spectrometric images by ordinary kriging and Inverse distance weighted interpolation techniques.- Analytical Chemistry, 80, 4896-4905.

Peng, J., Xu, Y.Q., Cai, Y.L. \& H.L. Xiao, 2011: Climatic and anthropogenic drivers of land use/cover change in fragile karst areas of southwest China since the early 1970s: a case study on the Maotiaohe watershed.- Environ Earth Science, 64, 2107-2118.

Raymond, P.A., Oh, N.H., Turner, R.E. \& W. Broussard, 2008: Anthropogenically enhanced fluxes of water and carbon from the Mississippi River.- Nature, 451, 449-452.

Spokas, K., Graff, C., Morcet, M., \& C. Aran, 2003: Implications of the spatial variability of land fill emission rates on geospatial analyses.- Waste Management, 23, 599-607.

Stallard, R.F. \& J.M. Edmond, 1981: Geochemistry of the Amazon: 1. Precipitation chemistry and the marine contribution to the dissolved load at the time of peak discharge.- Journal of Geophysical Research, 86, 9844-9855.

Stallard, R.F. \& J.M. Edmond, 1983: Geochemistry of the Amazon: 2. The influence of geology and weathering environment on the dissolved load.- Journal of Geophysical Research, 88, 967-9688.
Stallard, R.F. \& J.M. Edmond, 1987: Geochemistry of the Amazon: 3. Weathering chemistry and limits to dissolved inputs.- Journal of Geophysical Research, 92, 8293-8302.

Wakida, F.T. \& D.N. Lerner, 2006: Potential nitrate leaching to groundwater from house building.- Hydrological Processes, 20, 2077-2081.

Wang, B.L. \& Y. Wang, 1990: National key scenic spotsJinfo Mountain.- Sichuan Science and Technology Publishing House, pp.1-4, Chengdu, China.

Zhang, B., Xiao, F., Wu, H. \& S. Mo, 2006: Combating the fragile karst environment in Guizhou, China.Ambio, 35, 94-96.

Zhang, C., 2010: Seasonal variation of dissolution rate under the soil at different land uses and its influence factors: A case study of Jinfo Mountain, Chongqing.- Environ Earth Science, 56, 1, 136-140.

Zhang, C. \& D.X. Yuan, 2004: Hydrochemical variation of typical karst subterranean basin and its relationship with landuse change.- Journal of Soil and Water Conservation, 18, 5, 134-137.

Zhang, C., Yan, J., Pei, J.G. \& Y.J. Jiang, 2011: Hydrochemical variations of epikarst springs in vertical climate zones: a case study in Jinfo Mountain National Nature Reserve of China.- Environ Earth Science, 63, 375-381.

Zhu, X.Y. \& X.M. Qian, 2005: Groundwater Hydrology.China Environmental Science Press, pp. 68-110, Beijing, China. 